\title{
Gender Binary and the Limits of Poststructuralist Method
}

\section{Anna Krylova}

\section{Introduction}

In contemporary gender history, the story about the making of the gender category is inseparable from the concept of 'gender binary'. It at once signifies a research agenda and constitutes a persistent problem pervading feminist analysis itself. On the one hand, it points to the massive historical record of persistent inequality between the sexes. On the other hand, the concept of 'gender binary' undergirds gender history's analytics, which empowers historians to pursue, expose and deconstruct the binary organisation of gendered - woman/man - identities as well as social relations and discursive formations that produce them. In both its capacities, the concept carries a rich repertoire of connotations, which informs and influences the gender category: those of radical distinction, opposition, mutually exclusive and exhaustive differentiation, hierarchy, domination, oppression - in all their myriad historical forms. As a result, it captures the entanglement of gender - in theory, an open-ended category - in binary, that is, negatively - and positively determined connotations of feminine and masculine and, consequently, in a particular, historical form of heterosexual subjectivity, the one structured like a binary, hierarchal system.

The entanglement of gender history's foundational category - gender - in the heterosexual predicament and, consequently, binary systems of assigning difference has had many critics. The problem of 'pervasive heterosexism' in women's and gender history formed a founding critique of lesbian and gay studies and queer theory and continues to inform conversations in transgender and third genders studies. Over the last thirty years, these dynamic fields have exposed the poverty of gender as a binary device to analyse non-heterosexual experience and also pioneered theoretical approaches to gendered identities that do not fit the binary matrix and that exist outside the normative heterosexual paradigm. ${ }^{1}$

What has been left unexamined in this thriving research and what gives this article its focus is the poverty of gender as a binary device to analyse those gendered identities that constitute heterosexual relations but do not fit the binary matrix. Granted, scholars working in the fields of lesbian and gay studies, queer theory and transgender studies have not posited for themselves an agenda that would entail a thorough examination of historical intricacies of heterosexual subjectivities. Recognising that 'heterosexual 
practices are not the same as heterosexual norms', to quote Judith Butler, they nevertheless and quite deliberately have centred their critique on the 'heteronormative' that is, binary-structured - expectations of gendered life. ${ }^{2}$

In gender history - the primary site of critical interrogation of binary systems of signification and domination - the critical conversation about gender's entanglement in those binary systems has followed a different trajectory. Over the last thirty years, the field has turned the category of gender into a productive tool of feminist critique and, at the same time, articulated dissatisfaction with its analytical currency.

One of the oldest methodological critiques was and still is the charge of reification: the peculiar effect of gender analysis to reproduce the binary connotations of male and female difference and heterosexual subjectivity that scholars strive to undermine. This effect, for example, played a principle role in Joan Scott's committed promotion of poststructuralist theory and its deconstructive reading techniques as ways to remedy the situation. ${ }^{3}$

No less significant has been the accumulation of historical scholarship that documents a poor fit of the prevalent analytics to capture not only non-heterosexual cultures of difference but also heterosexual ones that do not warrant binary connotations of female-male distinction and invariably hierarchically structured relations between women and men. Speaking from research sites of early American and nineteenthand twentieth-century US history, African and African American history, Native American history, medieval and early modern European history, Russian history, Chinese history and South Asian history, its authors argue that not only does our established gender analysis allow us to reify what we strive to undo but it also conceals historical material that does not fit its parameters and enables scholars to force alternative ways of signifying and enacting woman/man distinction into proto-binary variations or treat them as exceptions or, in poststructuralist-inspired work, as subversions and transgressions. ${ }^{4}$ Most recently, different voices of this enduring conversation have been brought together in Jeanne Boydston's 2008 essay 'Gender as a Question of Historical Analysis'. In it, Boydston argued that even though this ongoing research into history outside the established gender analytics has not always directly addressed theoretical ramifications of its findings, it has foregrounded the need to further develop the field's theoretical apparatus. ${ }^{5}$

In what follows I join this critical conversation by taking the next step. I ask, how does one go about building a theoretical framework and analytical language to encompass specifically heterosexual phenomena that exist outside the normative, that is binary-bound, heterosexual paradigm, and that does not conceal but incorporate the history of alternative heterosexual gender systems? My goal is to enable the conditions for the continuous development - not abandonment - of the gender category, the achievement of several generations of historians. ${ }^{6}$ To do that, I take the critique of the limitations of gender analysis in a new direction. I contend that before we can continue to build on what we have, we need to gain a clearer understanding of those tenacious interpretive mechanisms that result in gender's much criticised effects of reification and concealment. How does a presumably open-ended category of analysis such as gender tend to reproduce the specific terms of the heteronormative imperative? Without explaining this unintended behaviour of gender analytics in our texts, we will not have a basis for moving forward. This query into the ways working categories and analytical tropes of gender history become 'bound up with' specific - at once, 
enabling and limiting - connotations and theoretical givens and, over time, obtain a life of their own forms the overarching problematic in this Forum. ${ }^{7}$ The question of gender's reifying and concealing properties requires of course the extended effort of more than one scholar. It entails a detailed re-evaluation of the ways the gender category became defined, theorised and turned into an interpretive practice in the midst of epistemological debates and theoretical innovation that overtook the US academy during the 1970 s through the 1990 s.

In this article, I propose to begin our exploration of how the gender category became a binary-reproducing category by undertaking a deconstructive reading of foundational work by one of the discipline's most influential theorists - Joan Scott. Having drawn on poststructuralist and psychoanalytical theory to combat gender's disconcerting propensity, Scott has continuously rethought the category and worked to develop its analytics for the past three decades. For these reasons, she may seem to be a counterintuitive point of departure.

And yet, it is precisely Scott's field-forming intellectual agenda - first, in the 1980 s, to define and theorise gender and then, in the subsequent decades, to put emergent gender theory into practice and to resist, ultimately unsuccessfully, as I show below, its binary properties - that makes a critical investigation of her field-shaping contribution a principal starting point. ${ }^{8}$ Below I trace this trajectory - from theorising gender to fighting its unintended outcomes - through Scott's forceful theoretical and methodological interventions: her most influential 1986 'Gender: A Useful Category of Historical Analysis'; her 1996 Only Paradoxes to Offer: French Feminists and the Rights of Man and her 2011 The Fantasy of Feminist History collection of essays where I pay special attention to the 'Fantasy Echo' essay. ${ }^{9}$ The reading strategy I deploy owes much to the method of deconstructive critique that Scott and her generation of gender scholars pioneered. I am interested as much in authors' stated intention as in their execution of their goals, and what is gained and lost in the process.

I argue that having identified the problem early on, Scott did not escape its predicament. In fact, her interrogation reveals an undergirding and unacknowledged paradox, not uncommon in historical scholarship informed by poststructuralist theory. ${ }^{10}$ While launching a penetrating critique of the deceptive fixity of binary systems of signification, Scott did not manage to step outside of their boundaries even though she masterfully deconstructed their internal modes of operations and demonstrated their instability and transgressive potentiality. Below I explicate this paradox of launching an ever-deepening deconstruction of the binary work of gender while staying within binary parameters - de facto reinforcing them - and, at times, sidestepping historical material that departs from normative expectations.

I conclude this article by addressing the problem of historical research on gendered, heterosexual identities that do not fit the binary matrix. I treat this problem as an opportunity to broaden our theoretical framework and propose to revisit the concept of dichotomy and differentiate it from binary connotations of difference found in heteronormative gender systems. The historical moment under consideration is the 'woman solider' in 1930s and 1940s Soviet Russia - a prevalent social identity that, in mainstream culture, state and military institutions and personal articulations and recollections, did not carry connotations of being an invariable and radical contradiction of terms, an oxymoron defiant of logic and history. 


\section{0s: The problem of 'fixed and permanent quality' of gender}

The problem of the seemingly 'fixed and permanent quality' of the 'binary opposition of male and female' and its reproduction in feminist scholarship formed the central question of Scott's 'Gender: A Useful Category of Historical Analysis'. It is thus worth recalling that the essay that was soon to become the main programmatic document of the field, habitually quoted to invoke definitive premises of gender analysis, started with a critical reflection about the analytical currency of this emergent category. For Scott, the crucial step in the continuing development of gender - the imperative that she set out for the field - depended on acknowledging and finding a way out of the following perplexing situation. How was one to approach a category that, by the 1980s, had announced historical contingency and social constructedness of sexual difference, and which had rejected biology as the explanation of inequality, but that nevertheless allowed scholars to recreate the 'binary opposition' as the 'central fact of gender'. ${ }^{11}$

According to Scott, the unsettling problem with gender, theorised 'within traditional social scientific framework', lay with the lack of scholarly attention to linguistic and discursive dimensions of social, political and institutional relations of gender inequality. ${ }^{12}$ To remedy this shortcoming, Scott proposed to probe the binary organisation of gender relations and approach gender as a complexly structured meaning-giving regime of signification and domination. Understood as such, the gender category, continued Scott, reached far beyond gender-explicit relations and discourses. The signifying system that Scott had in mind only appeared 'fixed and permanent'. Its internal operations were marked by profound instability, conflict, ambiguity and, at the same time, dogged perseverance and ingenious mutability. ${ }^{13}$ In the 1980s (just as today), one could detect unmistakably poststructuralist and Foucauldian underpinnings of this attempt to re-theorise the gender category and the binary opposition constitutive of it.

Drawing on Jacques Derrida's poststructuralist insights and poststructuralist literary theory by Barbara Johnson, Elizabeth Grosz and Elizabeth Weed, Scott argued that the impression of coherence and fixity that any binary system of signification strove to project was nothing more than an illusion - an ideological effect not to be recorded uncritically but to be interrogated as an outcome of 'conflicted', 'unstable' and 'ambiguous' processes of construction of meaning. ${ }^{14}$ The proposed new focus on 'conflictual' and 'unstable' processes at the heart of the production of binary connotations of female and male was paramount. The new goal was to expose the unattainability of fixed oppositions.

In 'Gender: A Useful Category of Analysis' and in a number of highly influential texts published between 1986 and 1988, Scott repeatedly explicated this reading of poststructuralist theory of linguistic processes and presented the 'work of gender' in history - an academic figure of speech that she coined for historians - as radically differentiating the 'Woman' and 'Man' categories into negatively- and positively-determined opposites. Scott's explication of this point on more than one occasion signals that in the mid- and late 1980s, notions of gender and binarity were not yet unquestionably synonymous. For example, in the introduction to her 1988 Gender and the Politics of History collection of essays, Scott still found it necessary to repeat that the organisation of any binary system including gender was 'usually hierarchal, with one term dominant, prior and visible, the opposite subordinate, secondary and often absent or invisible'. The binary work of gender, in other words, consisted of signifying processes in which 
radical differentiation - dominant/subordinate, prior/secondary, visible/invisible, positive/negative - constituted at once unstable and 'inherent' mechanisms of meaning making. ${ }^{15}$

Already in the 'Gender' article, Scott's theorisation of the 'work of gender' encompassed a lot more than unstable and conflictual processes, which would then be exposed by historians. Gender was unequivocally wedded to one more concept that broke into the historiographical debates of the period and offered another fruitful and, for Scott and gender historians, crucial venue to theorise and critique the binary organisation of gender difference - the Foucauldian concept of power. In Scott's reading, the concept stood for regimes of knowledge and domination, in their discursive and institutional incarnations, and foregrounded their self-regulating, self-modifying and stubbornly persevering mechanisms of operation. As a result, the 'work of gender' in Scott's publications acquired different modes of operation and alternated between phases of construction, legitimisation, contestation and maintenance. In 'Gender: A Useful Category of Analysis' in particular, the resultant vision of the production of gendered identities was of 'a necessary statement about inequality or power'. Gender emerged as a constantly adjusting and historically resourceful binary system. Challenges to such a system tended to be cancelled out by means of rearrangements and adjustments internal to the system itself. ${ }^{16}$

Having translated the conversation about gender into the poststructuralist and Foucauldian languages of binary oppositions and power, Scott provided historians with a theoretical rationale for treating gender binaries not simply as socially constructed but also as culturally unstable, self-modifying and self-perpetuating systems. There was of course an unacknowledged tension in this vision that insisted at once on instability and perseverance of meaning-giving regimes of domination. This tension notwithstanding, the new formulation seemed to address the effect of 'fixed' binary oppositions in feminist scholarship, the problematic with which the 'Gender' article had started.

The current conversation about Scott's 1986 intervention tends to stop at this point. ${ }^{17}$ Here I propose to take it to the next level by posing the following question: Did Scott's poststructuralist and Foucauldian reading of the binary work of gender expand the definitional parameters of the gender category itself beyond the connotations of binarity $?^{18}$ I argue that it did not. In fact, offering a deeper look into different layers of production, malfunction and perseverance of binary gender systems, the two theoretical approaches kept the analytical gaze of the scholar within the parameters of her starting problematic.

In 'Gender: A Useful Category of Analysis', potential limitations of Scott's poststructuralist intervention were already implicit in the way Scott defined the gender category and articulated a new methodological agenda for the field. Thus, in her paradigmatic definition that is still in use, gender - an open-ended category denoting 'perceived difference between the sexes' - gets narrowed down to one particular connotation of difference: the one 'signifying relationships of power'. Given the larger theoretical discussion in the essay, the 'power' concept carries connotations of binarity and domination; it de facto describes only one kind of heterosexual subjectivity, the one structured like a binary opposition. ${ }^{19}$ Among things left outside the proposed definition is, for example, a non-binary organisation of heterosexual identities. 
Scott's radical intervention thus embodies a classical paradox, one at the heart of her adaptation of the poststructuralist as well as Foucauldian approaches - the determination to resolve a problem from within, by means of submersing oneself in a critique of its unstable, conflictual and perpetuating operation. In such an approach, the boundaries of a problem under consideration constitute the boundaries of the intervention. The radical and yet, as I argue, self-constrained emancipatory approach consists at least of a 'disruption', 'questioning' and 'destabilisation' of the fixity of 'binary gender representation' and its self-propelling and self-regenerating mechanisms. Consequently, it promises nothing more than possibly creating conditions for an alternative way of thinking. Importantly, the possibility of an alternative is expected to arise from within an act of critique, and is relegated to the future. ${ }^{20}$ History, that is the past, is excused from being considered as a possible depository of alternative, non-binary, heterosexual gender formations.

\section{0s: Turning theory into a historical practice}

What the gender category, defined as a binary signifying system of domination - at once unstable and self-sustaining - could accomplish as a working category of historical analysis is best seen in the analytics it enabled. The 1990s and the early 2000s arguably constituted the most dynamic period in the history of gender analysis. The emergent field was akin to a nationwide laboratory in which practitioners explored different ways of translating vibrant theoretical discourses into analytical languages and modes of interpretation. Within this booming effort, Scott's contribution to the development of analytical languages of gender history went through several stages. Only Paradoxes to Offer - her first book-length deployment of new analysis published in 1996 represented one dominant direction of the 1990s. In it, Scott furthered deconstructive and discursive techniques of reading.

Delineating the scope and limits of her intervention, Scott begins Only Paradoxes to Offer by telling her reader that her story does not offer an escape from the massive historical record of binary thinking about sexual difference. Her historical protagonists - prominent French feminist thinkers who, over the course of nearly three centuries, attempted to critique and overcome conventional thinking about gender hierarchies at the core of heteronormative subjectivity - serve Scott as a case in point. Scott's story, in other words, is not about transcendence but entrapment in the very notions of inequality that one tries, in vain, to challenge and displace. Summarising the gist of her argument in the book's introduction, Scott writes: 'Feminism was a protest against women's political exclusion; its goal was to eliminate "sexual difference" in politics, but it had to make claims on behalf of "women" (who were discursively produced through "sexual difference"). To the extent that it acted for "women," feminism produced the "sexual difference" it sought to eliminate'. ${ }^{21}$

This summary contains the interpretive formula that informs Scott's first booklength deployment of theory onto historical material. In it, the French feminist tradition is implicated, at the fundamental level, in the tenaciously binary discourses on sexual difference that produce the normative heterosexual subject. Those discourses, in turn, constitute the boundaries of otherwise multiple, conflictual and mutable connotations that male and female identities take upon themselves. It is only within the limits of this 
formulation that it makes sense to argue, as Scott does in the above quote and throughout the book, that an attempt at articulating a political agenda on behalf of women (or any contesting invocation of womanhood) simultaneously contests and upholds the very binary logic that disqualifies women from the possession of political rights. It is also only within the limits of this formulation that processes of differentiation at work in the construction of female-male, heterosexual identities are treated as synonymous with processes of radical differentiation, i.e. binarisation.

For example, following this rationale, Scott reads the turn-of-the-twentiethcentury feminist agenda of Madeleine Pelletier as challenging the normative, maleidentified view of the 'universal individual' while repeatedly staying within its underlying logics. As a result, Scott carries out her analysis of Pelletier's alternative ways of claiming and displaying individuality strictly on the terms that Pelletier outspokenly rejects. In order to claim the status of an 'individual' of her time, Scott explains, Pelletier had no other choice but to 'stand in the masculine position', that is, to embrace male-identified, binary values and to emulate the male way of conduct and dress, on the one hand, and, on the other hand, to suppress the socially imposed female persona. Consequently, Pelletier's 'feminism', according to Scott, 'was not a means to enhance the social status of women, but a way of dissolving the category entirely'.22

Explicating the logic of her interpretation, Scott writes: 'but since individuality was figured as masculine, since masculine was as close to universalism as one could get, the refusal of feminine difference became synonymous with an avowal of the masculine'. Following this binary-informed interpretive framework where the terms 'masculine' and 'feminine' denote mutually exclusive opposites, respectively positively- and negatively-charged, Scott demonstrates how Pelletier's passionate and penetrating critique of the despicable feminine and experimentation with the desirable masculine (male attire being the most visible claim to the male subject position) invariably reproduces the work of binary dichotomies even in her defiant feminist agenda and lifestyle. ${ }^{23}$

In Scott's analysis of Pelletier's particular historical circumstance, the binary vision attains a totalising, all-consuming and wickedly inescapable presence. This paradoxical situation is precisely what Scott aspires to capture for us by means of her painstaking exposure of dense, nonlinear, intertwined and internally contradictory logics of binary discourses on sexual difference as they shape the lives of her historical protagonists. Scott's text is submerged into a critical deconstructive conversation about the binary operation of gender. Her goal is not to find alternatives to binary forms of heterosexual gendered identities in the past. It is to critique their constitution and operation, to uncover their subversive potential and to possibly create a window of opportunity in the present, so one could escape their totalising pretence in the future. ${ }^{24}$

The problem with such an approach is twofold. By launching a critique, a scholar inevitably replicates and thus reifies in her analysis, what she hopes to displace. Scott's text, just like Pelletier's life, resides in the binary universe that it strives to undermine. Secondly, and an even greater problem, is that the totality that Scott demonstrates on behalf of the binary work of gender might be over-stretched.

In the case of Pelletier's feminism, for example, how is one to account for her aspiration 'not to be a woman in the way society expects', the statement with which Scott begins her chapter on the feminist? ${ }^{25}$ Scott interprets this statement as Pelletier's 'entirely negative' relation to - that is, a rejection of - 'women's identity'. ${ }^{26}$ Yet, is 
this what Pelletier is saying? A different reading would suggest Pelletier's rejection of only one form of womanhood, the one that the society expects of her. The quote may also convey Pelletier's presumption of there being more than one way to be a woman. It might be worthwhile to reread Pelletier's entire agenda as possibly operating with more than one and not necessarily binary-structured notion of womanhood. Such a reading might explain how Pelletier could at once 'despise' the feminine (when it denotes inferior difference) yet never relinquish the category of 'woman' (which field of signification she devotes her life to expand). Likewise, her experimentation with male attire could be read as an understandable desire for male status and, at the same time, a refusal to treat male dress as only pertaining to men, and thus aspiring to change the very meaning of the male dress and the masculine.

The methodological approach that one finds in Only Paradoxes to Offer enables Scott to subject the binary work of gender to a thorough and masterful disclosure of its signifying routines and reproductions of heteronormative subject positions. But, it does not take her inquiry outside of those routines. As a result, Only Paradoxes to Offer delivers a trenchant critique of stubborn gender binaries that undergird historical discourses of feminism but also offers a case study of the reifying work of binary representation of sexual difference in contemporary academic literature.

\section{0s: Confronting the reifying work of gender}

The growing concern about the reifying tendencies that the newly theorised gender category displayed in academic literature marked the decade of the $2000 \mathrm{~s}^{27}$ To counteract this unnerving phenomenon, Scott proposed to continue developing gender history's analytics by turning to Lacanian psychoanalysis and its poststructuralist insight into psychological processes of normative identity formation. As her 2011 collection of essays Fantasy of Feminist History attests, she shifted the focus of her inquiry from studying the internal operation of normative discourses of heterosexual subjectivity to investigating the psychic dimensions of individual encounters with them. ${ }^{28}$ This shift, however, did not entail a critical interrogation of the binary parameters in which the category of gender continued to be constrained.

The critical potential of this new direction, Scott explained, would allow scholars to explore 'ruptures', 'fantasies' and 'transgressions', endemic to the modern subject's encounter with the scripts of normative heterosexuality and offset the reifying tendencies of gender analytics. By focusing her gaze on different aspects of this contradictory encounter, Scott hoped to capture individual subjects' perpetual failure to stay within the boundaries of the normative script. This new history of the 'ruptured' and 'transgressive' subject using the language of Lacanian psychoanalysis seemed to revive the emancipatory promise of theory. As Scott restated in the introduction, the goal still remained the same: to 'interrupt the certainty of established categories' and create 'openings in the future'. 29

To be sure, the proposed analytic enabled Scott to undertake a deeper and more nuanced study of the construction of normative heterosexuality, seen now as always upset and disrupted by transgressive fantasy and behaviour. But it did not deliver the desired result of offsetting the reifying work of gender as a binary-structured category of analysis. The overall strategy of focusing on subjects' transgressions in order to 'interrupt the certainty of established categories' once again, as in the case of the 
deconstructive method, did not remove those 'established categories' from Scott's analysis. ${ }^{30}$ Let us explicate this process as it unfolded in Scott's 2001 essay 'Fantasy Echo'.

Here, Scott explores fantasies of female transgression that proved to be 'particularly prevalent' in eighteenth- through twentieth-century European feminisms. ${ }^{31}$ Her focus on the female transgressive subject as it dreamt and acted in defiance of the norm does not, however, require Scott to abandon the normative discourse on sexual difference as the essay's chief historical background. Nor does it require that any non-binary categories of analysis be utilised. What is being problematised by invoking the analytics of transgression, in other words, is the process of becoming the heteronormative subject but not the parameters of that becoming.

It is not surprising that a method derived from Lacanian psychoanalysis has little to offer to resolve this analytical-methodological conundrum. The Lacanian school, in Scott's reading, does not aspire to create a beyond - an actual articulable position situated outside the presumed totality of phallocentric predicament of human existence. As Scott explains, relying on Slavoj Zizek, the play of the psyche's unconscious desires and urges pushes this Lacanian subject to transgress the restraints of the norm but this play exceeds articulation. ${ }^{32}$ As such, a transgression or a forbidden fantasy never amounts to anything more than a pleasurable (sometimes intensely pleasurable) and, at the same time, apprehensive and punishable 'disruption' of the heteronormative imperative - not its dismantlement or, to invoke Elizabeth Grosz's critique of poststructuralist theory, even an articulated intent to challenge it. ${ }^{33}$ What is implicit but not directly stated in Scott's attempt to theorise the transgressive subject on Lacanian terms is that, in Lacanian psychoanalysis, the heteronormative and the transgressive constitute codependent phenomena, belonging to the same system of domination. After transgressing one's circumstance, the transgressor still has no other ground to come back to, except the one being transgressed. Following such a theorisation of modern subjectivity, Scott has little choice but to implicate her historical actors into a narrative in which the binary predicament of human existence is presented as being continuously transgressed as well as continuously there - an inescapable arena of transgressive behaviour.

The reifying imperative of this interpretive position is exemplified in Scott's reading of the fantasy of 'the female orator'. By visualising a take-over of a public podium, the transgressive figure of 'the female orator', writes Scott, 'projects women into masculine public space' while relating 'experience' of 'pleasures and dangers of transgressing social and sexual boundaries'. Let us pause and reread the above interpretation of transgression. In it, the meaning of spaces and identities involved in the transgressive act remains remarkably intact. Public spaces retain their normative 'male' demarcation, even though they are being transgressed. Women at the podium are still seen as intruders, displaying 'inappropriate femininity' ${ }^{34}$ What has changed as a result of Scott's interpretation of the transgressive figure of the 'female orator'? It is still the heteronormative discourse of sexual difference that assigns meaning, for it is only from the heteronormative point of view that public spaces are supposed to be male and appropriate womanhood is seen as incompatible with public participation. At least on paper, Scott's transgressive subject does not so much interrupt as reify the binary, mutually exclusive connotations of male and female predispositions and roles. 
The problem with such a reading, once again, is not only the resultant proliferation and, thus, reification of binary connotations of female/male, feminine/masculine and heteronormative subject positions they inform. A larger problem is that, caught up in the confines of her analytics, Scott does not ask whether the binary parameters of the gender category can encompass her historical material.

Interrogating gendered fantasies of one of her historical protagonists, a feminist icon of the French Revolution, Olympe de Gouges, Scott writes that de Gouges 'saw nothing transgressive in her own public activity'. As Scott explains, de Gouges 'did not accept the gendered boundaries between public and private'. ${ }^{35}$ Pointing to de Gouges's clear rejection of binary gendering of public and private spaces, this explanation nonetheless does not allow Scott to probe the issue beyond the limitations of binary representations: if de Gouges did not see her mode of being a woman and a public persona as transgressive, what gendering logic - that is, what (possibly nonbinary) connotations of womanhood and thus manhood - enabled her to hold such a belief? Bypassing these questions, Scott keeps her interpretive options within the binary universe.

The question that I want to raise again is whether, as in the case of Pelletier's invocation of a concept of the woman on other than normative terms, de Gouges's refusal to characterise herself as a transgressor might offer gender historians a window of opportunity to investigate the possibility of a historical beyond to the binary-structured, normative meanings of heterosexual systems. Instead of reading challenges to normative significations of gender relations exclusively from within those significations, why should we not investigate what gendering logic, even if not prevalent, allowed a female public activity to seem non-transgressive?

\section{The problem of non-binary heterosexual gender systems}

The limitations of the longstanding framework - which investigates the complex ways binary systems function (and malfunction) but maintains the confines of those systems - come into sharp relief when scholars encounter cases of heterosexual subjectivity that do not rely on the language of binary opposition alone. Let me clarify the kind of historical phenomena the growing body of scholarship discussed in the introduction has been preoccupied with. ${ }^{36}$ What is under consideration is not simply individual instances of breaking or stepping outside the binary norm. Nor is this scholarship referring to those fleeting moments of subversion or transgression, filled with sensations of pleasure for which a subject has no language to account for. At the centre of this research are social phenomena accompanied by developed cultural languages that allow historical subjects to articulate and enact female and male identities without relying on binary connotations of difference.

In my research on modern Russia, I came across a heterosexual subject that did not speak the language of gender binarity when I explored the historical phenomenon of Soviet young women's volunteering for combat in the Second World War. One of the first memoirs by a female veteran that I read, Zoia Medvedeva's The Youth Burned by Fire, introduced me to the unfamiliar gendering logic of her recollections. ${ }^{37}$ Early in her memoirs, Zoia remembers how she, having passed through several levels of civil and military bureaucracy and been trained as a machine-gunner, arrives at the frontline near Odessa in the summer of 1941 as a 'woman-soldier'. She used a state-issued 
document to confirm an identity that, from the binary point of view, can be nothing but a contradiction of terms. Her claim undoubtedly provoked resistance and emotional turmoil among male combatants. But this predictable reaction - the privileged moment in the established scholarly narrative about Soviet women's participation in combat was by no means inescapable and all pervasive at the Soviet front either in 1941 or throughout the war. ${ }^{38}$

Zoia, for example, also met her immediate commander, a young man who was far from certain about what exactly constituted women's appropriate role in the war effort. For him, the concept of a woman was an open-ended question. Zoia's other early frontline acquaintance was a male medical orderly characterised by her as a 'born' nurse - a male care-taker by nature. Unlike herself - a 'born' woman-soldier - he was not interested in combat. A year later, at the age of twenty Zoia became a female commander of a male machine-gun platoon. The gender landscape around her and other female soldiers and officers remained strikingly irreducible, in her narration, to binary signification of male and female essences, characters and roles. At no point in her memoirs is women's volunteering to the front presented in binary terms of female entrance into a male space. The front, according to Medvedeva's generation, was not without gender but it did not operate as an omnipresent binary enterprise. Had it done so, the Soviet war effort would have been divided into mutually exclusive female and male spaces, awarded different significance.

The questions that Medvedeva's generation posited to prevalent analytical parameters of gender and heterosexual subjectivity seemed promising. If not binary, what concept of gender (that is, what concept of female/male difference) formed those lives and recollections? And what theoretical framework can capture it? (Pragmatic accounts that point to the desperate state of the Soviet army lose their explanatory power the moment one reminds oneself that neither young women who volunteered in the summer of 1941 nor largely male officers who recruited them knew about the unfolding catastrophe on the Soviet front.)

These questions provided the impetus for what became Soviet Women in Combat: A History of Violence on the Eastern Front and this article. It was the way Zoia and her generation gave meaning to female and male combatants, the front, and Soviet pre-war and wartime society and challenged the prevailing academic narrative that stressed the 'reversal' of radical Bolshevik gender agendas in the mid-1930s that formed the main inquiry of the book. ${ }^{39}$ In her recollections, for example, Zoia erases the binary distinction between the female home front and the male front and between female identities (being negative and subordinate) and male identities (being positive and dominant) without shattering the female/male distinction itself or its claim to represent the universal state of humanity. Thus, 'women-soldiers' - a prevalent identity category found in pre-war and wartime mainstream culture, state and military documents as well as private letters - are not described by Zoia as a self-evident contradiction assembled out of binary parts (as they would have been if one had read them from the binary point of view): that is, as 'masculine women', enacting or mimicking male behaviour. Far from it, the social identity of a 'women-soldier' constitutes what the Soviet society referred to as a 'different concept of a woman' whose feminine qualities were not seen as necessarily compromised. Rather, they were informed with new connotations of the feminine. For example, following Zoia's logic, I read the presence of red poppies at her gun site (marking one's combat space with flowers was a common preoccupation 
among women-soldiers) not as an importation of conventional femininity into the male trenches but as women combatants' attempt to change the very meaning of the feminine, to detach femininity from its binary associations with weakness and debilitating frivolity and to visually change the gender map of combat spaces. Likewise, male nurses do not play the role of 'effeminate men' in Zoia's memoirs (as they would have been if, again, one had read them from the binary point of view) but a different kind of men. The very connotations of the female and the male utilised by Zoia are no longer dependent on the logic of binary distinction. The articulation of heterosexual difference, as a result, follows different rules. ${ }^{40}$

In Zoia's memoirs, if we take a closer look, no heterosexual identity is binarybound, that is, presented as either negative or positive: male nurses are neither better nor worse than female soldiers. Thus, 'women soldiers', 'male nurses' and categories 'woman' and 'man' that inform Zoia's memoirs do not form a radical negation of each other and are not a priori either negatively or positively determined. Having parted company with binary representation of male/female impermeable difference, Zoia presents the reader to different types of women and men. No longer congregating in two negatively- and positively-determined camps, 'men' and 'women' are distributed along a continuum of being: some men are nurses, some are soldiers whose daughters are also soldiers, some women are officers, some are wives staying at home. In the resultant, still dichotomous universe (since Zoia and her contemporaries do not allow for a normative possibility that, for example, one could be neither female nor male), there is no single positive standard - either male or female - that encompasses everyone and every quality.

Thus, in Soviet Women in Combat, I argue that our understanding of the sociocultural phenomenon that Zoia and her generational cohort capture requires broadening our definitional parameters and theoretical expectations of the category of gender. How does one reconfigure this category in order to encompass the kind of heterosexual subjectivity operative in Zoia's text? And how does one categorise the kind of dichotomous thinking at work in the examples given above?

The Soviet case offers us a striking reminder that a binary way of thinking does not exhaust the realm of possibilities of thinking about heterosexual difference. In fact, Zoia's memoirs point to the marginalised distinction between dichotomous and binary connotations of difference in the field of gender history. Unlike binary, dichotomy is a more general category that does not presuppose a necessary assignment of value, either negative or positive, to its parts. The parts or 'opposites' of a dichotomous system should not be understood literally - as oppositional. I propose to take advantage of the underused connotations of dichotomous categories as dividing the universe into two mutually exhaustive groups/opposites while not necessarily carrying connotations of negative and positive value. I argue, as a result, that what is at work in the examples given above is a different kind of dichotomous thinking: a non-binary one. Nonbinary dichotomies (man/woman) capture a different mechanism of production of heterosexual subjectivity. ${ }^{41}$

Given the established near-conflation of the terms 'dichotomous' and 'binary' in the field of gender history I am aware that this theoretical move - to stretch the category of gender when applied to the study of heterosexuality to include the concept of nonbinary dichotomy - might sound contradictory and counter-intuitive to many historians. This is not the case in all disciplines however. In contemporary feminist philosophy, 
contrary to the situation in the field of gender history, one finds little consensus about the meaning of the term 'dichotomy'. In her 'Categories and Dichotomies' entry in the Encyclopedia of Feminist Theories, feminist philosopher Marilyn Frye, for example, explains that, some feminist thinkers believe that the 'definition of dichotomous leaves the possibility open' to treat opposite genders as 'interdependent, with neither being [necessarily and trans-historically] dominant or subordinate'. On the other hand, other feminists 'think either that this is impossible in contemporary society, or that dichotomy necessarily implies hierarchy' ${ }^{42}$ Resolving this debate, I believe, will require the input of historians - both of heterosexual and queer identity - for whom the differentiation between dichotomous and binary modes of constructing and enacting heterosexuality offers the condition of possibility for the development of gender analytics that would account for and, as importantly, critique the historical complexities of heterosexual gender systems.

To conclude, the kind of gendered imagination captured by Zoia's memoirs was by no means an anomaly. It was characteristic of the Soviet society before and during the war - it was foundational for its pre-war education system, foregrounded in popular culture, prevalent in state documentation, party, youth and military organisations. And yet, in Soviet Women in Combat, I do not argue that the binary imperative was overcome, transformed, triumphed over and gone. Instead, I trace how it was de-centred and explore the opportunity this afforded for imagining, articulating, institutionalising and enacting alternative ways of being a 'woman'. As a result, the book ends with a question. I ask whether the now-prevalent historical claims of Soviet socialism's marked failure to fulfil its radical revolutionary promise on behalf of women can accurately represent the meaning of the Soviet 'woman question' and gender agendas of the Soviet state during the first three post-revolutionary decades.

\section{Conclusion: Gender as an ongoing theoretical project}

Joan Scott's highly influential and vibrant scholarship has served here as a case study to examine what happens to a field's analytics when a problem it pursues is written into the definitional parameters of its master category. To begin addressing this problem, this article traced how the presumably open-ended category of gender became entangled in binary connotations of sexual difference and poststructuralist analytics and was de facto reduced to one particular historical form of heterosexuality that reproduced binary logics in gender scholarship.

I have argued that in order to continue to contest the reifying work of binary analytics, this mode of thinking about heterosexual subjectivity needs to be challenged. This not only requires the counter examples one finds in the rich historiography discussed in the introduction but also purposeful re-conceptualisation of the gender category. The work of defining and theorising gender for the study of heterosexual gender systems, in other words, is far from being complete. The gender category needs to undergo a radical expansion to become a category that encompasses non-binary modes of thinking about woman- and man-identities even in heterosexual systems. The inquiry into what kind of relations of domination non-binary heterosexual gender systems have (and have not) supported must form a paramount research direction. 
The work of the historian pursuing this agenda would become more difficult and less predictable. The challenge would be not to impose a binary reading onto any invocation of female/male distinction but to explore how difference is produced, keeping in mind that not all dichotomies must be necessarily binary. This way, the historical site of heterosexual subject formation itself would be positioned as (sometimes) a site of contestation - both of heteronormative ideology of the time, and binary analytics itself.

\begin{abstract}
Notes
I am deeply grateful to Judith Walkowitz, Tani Barlow, and Mary Louise Roberts for their ongoing intellectual generosity, critical insights, and valuable engagement that shaped this article. More thanks to Gabrielle Spiegel and Elizabeth Grosz for their counsel and for guiding me through the fields of theory of history and feminist philosophy. I also owe much to Antoinette Burton, Dirk Bonker, Tracey Deutsch, Francisca de Haan, Karen Krahulik, Claudia Koonz, Afsaneh Najmabadi, Andrew Sartori and Carol Symes for their good will, thoughtful criticisms and encouragement to break new grounds. The first draft of this article was written during my term at the National Humanities Center, and I thank this institute and the fellow members of the History and Theory Seminar for creating one of the most stimulating intellectual communities I have participated in since my graduate school years.
\end{abstract}

1. One of the analytical, long-term goals posited by Judith Butler in her 1990 classic Gender Trouble, for example, was precisely to resist prevalent interpretations of butch and femme identities as 'simple copies of heterosexual masculinity and heterosexual femininity'. See Butler's explication of this point in Judith Butler, 'The Question of Social Transformation', Undoing Gender (New York: Routledge, 2004), pp. 204-31, here p. 209. See also, for example, David Valentine, Imagining Transgender: An Ethnography of a Category (Durham: Duke University Press, 2007); Judith Halberstam, The Queer Art of Failure (Durham: Duke University Press, 2011); Biddy Martin, 'Sexualities without Genders and other Queer Utopias,' diacritics 24, no. 2/3 (1994), pp. 104-21; Gilbert Herdt (ed.), Third Sex, Third Gender: Beyond Sexual Dimorphism in Culture and History (New York: Zone Books, 1994); Sabrina Petra Ramet (ed.), Gender Reversals and Gender Cultures: Anthropological and Historical Perspectives (New York: Routledge, 1996); Joanne Meyerowitz, How Sex Changed: A History of Transsexuality in the United States (Cambridge: Harvard University Press, 2004); Afsaneh Najmabadi, Women with Mustaches and Men without Beards: Gender and Sexual Anxiety of Iranian Modernity (Berkley: University of California Press, 2005); Sharyn Graham Davies, Challenging Gender Norms: Five Genders among the Bugis in Indonesia (Belmont: Wadsworth, 2006); Michael Peletz, Gender Pluralism: Southeast Asia since Early Modern Times (New York: Routledge, 2009); William G. Clarence-Smith and Raquel Reyes (eds), Sexual Diversity in Asia, c. 600-1950 (New York: Routledge, 2013); Mark Rifkin, When Did Indians become Straight? Kinship, the History of Sexuality, and Native Sovereignty (Oxford: Oxford University Press, 2011); for earlier critical inquiries, see the issue on 'Queer Theory' of differences 3/2 (1991), especially Teresa de Lauretis, 'Queer Theory: Lesbian and Gay Sexualities', differences 3/2 (1991), pp. iii-xviii. See also Adrienne Rich, 'Compulsory Heterosexuality and Lesbian Experience', Signs 5 (1980), pp. 631-60.

2. Butler, Undoing Gender, p. 199.

3. Joan W. Scott, 'Gender: A Useful Category of Analysis', American Historical Review 91 (1986), pp. 1053-75. Here and below, page numbers are from Joan W. Scott, 'Gender: A Useful Category of Analysis', in Joan W. Scott, Gender and the Politics of History (New York: Columbia University Press, 1999), pp. 28-50, here pp. 32-3; also Joan W. Scott, 'Preface to the Revised Edition', in Scott (ed.), Gender and the Politics of History, pp. ix-xiii, here p. xii; Joan W. Scott, 'Unanswered Questions', American Historical Review 113 (2008), pp. 1422-30, here p. 1424; Joan W. Scott, 'Introduction', The Fantasy of Feminist History (Durham: Duke University Press, 2011), pp. 1-22. For a critical discussion of the reifying work of gender, see Jeanne Boydston, 'Gender as a Question of Historical Analysis', Gender \& History 20 (2008), pp. 558-83; Afsaneh Najmabadi, 'Are Gender and Sexuality Useful Categories of Analysis?', Journal of Women's History 18/1 (2006), pp. 11-21; Tani E. Barlow, The Question of Women in Chinese Feminism (Durham: Duke University Press, 2004); Tani E. Barlow, 'Response', Journal of Women's History 20/1 (2008) pp. 231-6; for Antoinette Burton's discussion of Najmabadi's and Barlow's work and her critique of the 'binary sex-gender system from which much of women's history has proceeded' see Antoinette Burton, 'Parsing the Woman Question, Rethinking Feminist History', Journal of Women's History 20/1 (2008), pp. 217-20, here p. 219. 
4. See, for example, Regina Kunzel, Fallen Women, Problem Girls: Unmarried Mothers and the Professionalization of Social Work, 1890-1945 (New Haven: Yale University Press, 1993); Mary Beth Norton, Founding Mothers and Fathers: Gendered Power and the Forming of American Society (New York: Knopf, 1996); Clare Lyons, Sex Among the Rabble: An Intimate History of Gender and Power in the Age of Revolution, Philadelphia, 1730-1830 (Durham: University of North Carolina Press, 2006); Joyce Ladner, Tomorrow's Tomorrow: The Black Women (New York: Doubleday, 1971); Rosalyn Terborg-Penn, African American Women in the Struggle for the Vote, 1850-1920 (Bloomington: Indiana University Press, 1998); Jennifer Morgan, Laboring Women: Reproduction and Gender in New World Slavery (Philadelphia: University of Pennsylvania Press, 2004); Stephanie Camp, 'Ar'n't I a Woman? in the Vanguard of the History of Race and Sex in the United States', Journal of Women's History 19/2 (2007), pp. 146-50; Karen Anderson, Chain her by One Foot: The Subjugation of Native Women in Seventeenth Century New France (New York: Routledge, 1991); Nancy Shoemaker, A Strange Likeness: Becoming Red and White in Eighteenth Century North America (Oxford: Oxford University Press, 2004); Oyeronke Oyewumi, The Invention of Women: Making an African Sense of Western Gender Discourses (Minneapolis: University of Minnesota Press, 1997); Ifi Amadiume, Male Daughters, Female Husbands: Gender and Sex in an African Society (London: Zed Books, 1987); Thomas W. Laqueur, Making Sex: Body and Gender from the Greeks to Freud (Cambridge: Harvard University Press, 1990); Carol J. Clover, 'Regardless of Sex: Men, Women, and Power in Early Northern Europe', Speculum 68 (1993), pp. 1-28; Barlow, The Question of Women in Chinese Feminism; Najmabadi, Women with Mustaches and Men without Beards; Anna Krylova, Soviet Women in Combat: A History of Violence on the Eastern Front (Cambridge: Cambridge University Press, 2010).

5. Boydston, 'Gender as a Question', pp. 568-70.

6. My commitment to preserving the gender category by developing it to encompass what I will call at the end of this essay non-binary modes of signification of heterosexual difference sets this intervention apart from Boydston's, which called into question scholars' very reliance on the gender category. See Boydston, 'Gender as a Question', p. 559.

7. In this Forum, see Mary Louise Roberts's reading of reifying, heteronormative logics that, as she demonstrates, inform the work of the 'gender crisis' trope in feminist scholarship; Linda Gordon's interrogation of changing analytics and political agendas undergirding the history of the 'intersectionality' concept in feminist theory; and Lynn Thomas's explication of how scholars of Africa at once resist popular racial stereotypes in and outside academia and confer simplified conceptions of 'agency' on their gendered historical subjects. Mary Louise Roberts, 'Beyond “Crisis” in Understanding Gender Transformation', Gender \& History 28 (2016), pp. 357-65; Linda Gordon, “Intersectionality”, Socialist Feminism and Contemporary Activism: Musings by a Second-Wave Socialist Feminist', Gender \& History 28 (2016), pp. 339-56; Lynn Thomas, 'Historicising Agency', Gender \& History 28 (2016), pp. 323-38.

8. In 2008, Joanne Meyerowitz, for example, writing for the American Historical Review's forum on Scott's 1986 formative article, 'Gender: A Useful Category of Historical Analysis', characterised Scott's theorisation of the gender category as the shared property of the field of gender history, that is, 'a voice from the recent past, stating eloquently what everybody, it seems, already knew'. Joanne Meyerowitz, 'A History of “Gender", American Historical Review 113 (2008), pp. 1346-56, here pp. 1347, 1352.

9. Joan W. Scott, Gender and the Politics of History; Only Paradoxes to Offer: French Feminists and the Rights of Men (Cambridge: Harvard University Press, 1996); Joan W. Scott, The Fantasy of Feminist History.

10. My preoccupation here is not with poststructuralist theory per se (nor do I believe that 'poststructuralist theory' can be discussed as a unified and singular phenomenon) but with poststructuralist analytics, a mode of analysis that Scott derived from poststructuralist theorists.

11. In her critique of leading schools of feminist thought, Scott explicated this paradox. Even though theorists of patriarchy, for example, 'take into account the existence of changing forms and systems of gender inequality', they, Scott argued convincingly, nevertheless end up reproducing a master narrative in which 'history becomes, in a sense, epiphenomenal, providing endless variations on the unchanging theme of a fixed gender inequality'. Scott, 'Gender: A Useful Category of Analysis', pp. 32-5, 40. On the 1970s and early 1980s theorisation of the sexual difference as a social-cultural construct such as in 'sex/gender system', 'gender system' and 'gender category', see Gail Rubin, 'The Traffic in Women: Notes on the "Political Economy" of Sex', in Rayna Rapp Reiter (ed.), Toward an Anthropology of Women (New York: Monthly Review Press, 1975), pp. 157-210, where the author develops the concept of the "sex/gender system' in which both sexual and gender differences are theorised as 'cultural impositions', p. 170; Leonore Davidoff, 'Class and Gender in Victorian England: The Diaries of Arthur J. Munby and Hannah Cullwick', Feminist Studies 5 (1979), pp. 86-141, which captures the evolving mode of gender analytics; also, Michelle Zimbalist Rosaldo, 'Women, Culture, and Society: A Theoretical Overview', in Michelle Zimbalist Rosaldo 
and Louise Lamphere (eds), Women, Culture, and Society (Stanford: Stanford University Press, 1974), pp. 17-42; Natalie Zemon Davis, 'Women's History in Transition: The European Case', Feminist Studies 3 (1976), pp. 83-103; Judith L. Newton, Mary P. Ryan and Judith R. Walkowitz, 'Editors' Introduction', in Judith L. Newton, Mary P. Ryan and Judith R. Walkowitz (eds), Sex and Class in Women's History (New York: Routledge, 1983), pp. 1-15.

12. Scott, 'Gender: A Useful Category of Analysis', pp. 31, 40-41.

13. Scott, 'Gender: A Useful Category of Analysis', pp. 40-41

14. Scott, 'Gender: A Useful Category of Analysis', p. 43.

15. Scott, 'Introduction', Gender and the Politics of History, pp. 6-7; see also Scott's elaboration of the poststructuralist concept of 'difference' in Joan W. Scott, 'Deconstructing Equality-Versus-Difference: Or, the Uses of Poststructuralist Theory for Feminism', Feminist Studies 14 (1988), pp. 32-50, here pp. 36-7.

16. Scott, 'Gender: A Useful Category of Analysis', pp. 31, 42, 49; for Scott's elaboration of the Foucauldian concepts of discourse and power, see Scott, 'Deconstructing Equality-Versus-Difference', pp. 35-6.

17. See, for example, the 2008 American Historical Review forum on Scott's 'Gender: A Useful Category of Analysis': Meyerowitz, 'A History of “Gender”; Dyan Elliott, 'The Three Ages of Joan Scott', American Historical Review 113 (2008), pp. 1390-403; Maria Bucur, 'An Archipelago of Stories: Gender History in Eastern Europe', American Historical Review 113 (2008), pp. 1375-89. According to its contributors, the 'Gender' article offered a forceful analytical diagnosis of pressing problems of women's history as well as an equally forceful and field-defining solution, largely unburdened by paradoxes and contradictions. See also, Elizabeth Weed's close and illuminating reading of Scott's work which, nevertheless, does not problematise inherent limitations of her theorisation of the gender category, Elizabeth Weed, 'From the "Useful" to the "Impossible" in the Work of Joan W. Scott', in Judith Butler and Elizabeth Weed (eds), The Question of Gender. Joan W. Scott's Critical Feminism (Bloomington: Indiana University Press, 2011), pp. 287-311; Judith M. Bennett, History Matters. Patriarchy and the Challenge of Feminism (Manchester: Manchester University Press, 2006), pp. 17-18.

18. A recent notable exception to treating Scott's 1986 article as an accepted solution is Boydston's 'Gender as a Question of Historical Analysis'. In her critical intervention, Boydston overlooks the poststructuralist terms of Scott's analysis and thus bypasses that which made Scott's 1986 intervention an intervention - her re-theorisation of gender as a poststructuralist category. Boydston, 'Gender as a Question', pp. 562-3. For interrogations of poststructuralist premises in Scott's writing, see Claudia Koonz's close-reading review of Scott's Gender and the Politics of History in Claudia Koonz, 'Review: Joan Scott, Gender and the Politics of History', The Women's Review of Books 6 (1989), pp. 19-20; Kathleen Canning, 'Feminist History After the Linguistic Turn: Historicizing Discourse and Experience', Signs 19 (1994), pp. 368-404; Geoff Eley and Keith Nield, The Future of Class in History. What is Left of the Social? (Ann Arbor: The University of Michigan Press, 2007), pp. 101-19; Luisa Passerini, 'Review of Joan Scott's The Fantasy of Feminist History', Gender \& History 25 (2013), pp. 388-9.

19. Scott, 'Gender: A Useful Category of Analysis', p. 42.

20. For Scott's passionate explication and defence of the power of poststructuralist critique that leaves its inbuilt limitations unaddressed, see Joan W. Scott, 'Against Eclecticism', differences 16/3 (2005), pp. 114-37. In its revised form, the article also appeared as Joan W. Scott, 'History-writing as Critique', in Sue Morgan, Keith Jenkins and Alun Munslow (eds), Manifestos for History (London: Routledge, 2007), pp. 19-38.

21. Scott, Only Paradoxes, pp. 3-4.

22. Scott, Only Paradoxes, pp. 126, 131.

23. Scott, Only Paradoxes, pp. 134-5, see also pp. 137-8.

24. For Scott's discussion of her reading method, see Scott, Only Paradoxes, pp. 16-17.

25. Scott, Only Paradoxes, p. 125.

26. Scott, Only Paradoxes, p. 125.

27. In this forum, see Mary Louise Roberts's illuminating critique of the 'gender crisis' trope as a carrier of an implicit script of heteronormative subjectivity and thus performing the work of reification of hierarchal connotations of heterosexuality in feminist scholarship. Roberts, 'Beyond "Crisis". Also see endnote 3 above.

28. For Scott's discussion of her different agendas in Only Paradoxes to Offer and The Fantasy of Feminist History, see Joan W. Scott, 'Fantasy Echo. History and the Construction of Identity', in Scott, The Fantasy of Feminist History, pp. 45-67, here pp. 46-7; and Joan W. Scott, "Introduction. "Flyers into the Unknown": Gender, History, and Psychoanalysis', in Joan W. Scott, The Fantasy of Feminist History, 1-22, here pp. $11-15,19-20$.

29. Scott, 'Introduction. "Flyers into the Unknown", , p. 22, see also pp. 2-3.

30. Scott, 'Introduction. "Flyers into the Unknown", , p. 22. 
31. Scott, 'Fantasy Echo', p. 54

32. Scott, 'Fantasy Echo', pp. 49-50.

33. Scott, 'Fantasy Echo', p. 51; Elizabeth Grosz, 'Derrida and Feminism: A Remembrance', differences 16/3 (2005), pp. 88-94.

34. Scott, 'Fantasy Echo', pp. 54-5, 57.

35. Scott, 'Fantasy Echo', p. 55.

36. See Introduction to this essay and endnote 4.

37. Z. M. Smirnova-Medvedeva, Opalennaia iunost. Voennye memuary [The Youth Burned by Fire. (Military Memoirs)] (Moscow: Voenizdat, 1967). The analysis below comes from Krylova, Soviet Women, pp. 7-10.

38. For a discussion of dominant narratives in military and gender history devoted to Soviet women's role in the Second World War, see Krylova, Soviet Women, pp. 29-30.

39. On the academic discourse that treats the mid-1930s as a conservative turning point in Soviet gender history, see Krylova, Soviet Women, pp. 22-3.

40. Krylova, Soviet Women, pp. 17-18.

41. In Soviet Women in Combat, I refer to this different deployment of gender and articulation of female/male difference as 'nonoppositional though still binary', language which I now consider misleading and confusing. I believe that the language of 'non-binary' construction of difference and the extension of gender to encompass non-binary dichotomies that I develop here more accurately and effectively captures the historical phenomena under consideration. I want to thank Elizabeth Grosz for discussing this issue with me; for more on binary and dichotomous categories, see Nancy Jay, 'Gender and Dichotomy', in Sneja Marina Gunew (ed.), A Reader in Feminist Knowledge (New York: Routledge, 1991), pp. 89-106; Marilyn Frye, 'Categories and Dichotomies', in Loraine Code (ed.), Encyclopedia of Feminist Theories (New York: Routledge, 2000), pp. 78-9; Naomi Zack, Inclusive Feminism: A Third Wave Theory or Women's Commonality (Oxford: Rowman \& Littlefield Publishers, Inc., 2005).

42. Frye, 'Categories and Dichotomies', pp. 78-9. 